\title{
Primary School Teachers' Resilience during the Economic Crisis in Greece
}

\author{
Anastasia Botou ${ }^{1}$, Iro Mylonakou-Keke², Ourania Kalouri ${ }^{3}$, Nikolaos Tsergas ${ }^{4}$ \\ ${ }^{1}$ Greek Ministry of Education, Athens, Greece \\ ${ }^{2}$ Pedagogical Department of Primary Education, School of Education, National and Kapodistrian University of Athens, \\ Athens, Greece \\ ${ }^{3}$ Department of Pedagogy, School of Pedagogical and Technological Education, Athens, Greece \\ ${ }^{4}$ Department of Social, Political and Economic Sciences, School of Social Administration, Democritus University of Thrace, \\ Komotini, Greece \\ Email: botouanastasia@gmail.com, imylon@primedu.uoa.gr, rkalouri@aspete.gr, tsergasnik@yahoo.gr
}

How to cite this paper: Botou, A., Mylonakou-Keke, I., Kalouri, O., \& Tsergas, N. (2017). Primary School Teachers' Resilience during the Economic Crisis in Greece. Psychology, 8, 131-159.

http://dx.doi.org/10.4236/psych.2017.81009

Received: December 9, 2016

Accepted: January 13, 2017

Published: January 17, 2017

Copyright (c) 2017 by authors and Scientific Research Publishing Inc. This work is licensed under the Creative Commons Attribution International License (CC BY 4.0).

http://creativecommons.org/licenses/by/4.0/

\begin{abstract}
The economic crisis has had economic, social and professional consequences on teachers with the result that challenges and adversity they face have significantly increased. Resilience helps the individual face these adversities and difficulties and is built through the individual's dynamic interaction with his/her environment. In order for teachers to face increased challenges and setbacks created by the economic crisis they are required to have resilience. This paper presents a research carried out in Greece aiming to assess the correlation between resilience of primary school teachers who work in Athens (the capital of Greece) and the parameters that are associated with the economic crisis. The present research has found that more than half of primary school teachers who participated in it show moderately high and high resilience and at the same time a very small percentage has very low and low resilience. Furthermore, the Greek teacher's resilience has been influenced by the economic crisis at a moderate level. It seems that teachers in Athens, despite the fact that they have been experiencing difficulties due to the crisis, are still facing them at a good level. An important finding is that the Greek teacher's resilience is very highly correlated to his/her relationship with his family and his/her colleagues. In Greece family nexus is still very strong. The Greek teacher is supported by a strong network of relationships that s/he establishes with his/her family members and his/her colleagues. This network of relationships seems to support and strengthen the features that make up resilience.
\end{abstract}

\section{Keywords}

Teacher Resilience, Financial Crisis, Family Relationships, Colleague Relationships, Educational System 


\section{Introduction}

In recent decades research on resilience has expanded from children to adults, especially to teachers (Le Cornu, 2009). Moreover, the purpose of the research has expanded to the level of school units and classes, taking special conceptual dimensions. Strengthening of classes and their function as protective factors for learning and developing skills is a particular dimension of educational resilience (Cefai, 2007; Goldstein \& Brooks, 2007; Doll et al., 2014).

Teachers' resilience is linked with the effectiveness of education ( $\mathrm{Gu} \&$ Day, 2007; Gu \& Day, 2013), job satisfaction and with the quality of the educational process. Resilience constitutes a dynamically developing field of investigation in social sciences, where significant scientific developments are observed, aiming to "promote health and well-being" of certain social groups (Kolar, 2011: p. 431).

This research aims to examine primary school teachers' resilience in the greater urban area of Attica under the conditions of severe economic crisis, which has been affecting Greece for years now. This period was chosen for the present research because it is of particular interest, as teachers have been affected by a bunch of complex negative economic and social consequences.

The interest of the study of teachers' resilience lies in the fact that the Greek reality is constant and opposite to what is observed in some western and other countries over time, in which a high proportion of teachers leave education in the early years of their recruitment (McCann \& Johanneson, 2004; Hong, 2012). In contrast, in Greece the percentage of teachers that leave education is very small, almost insignificant. This reality has not changed despite the adverse impact of the widespread economic crisis and the fact that teachers are weighed down at work, economic and psychological level. Between the years 2009/10$2012 / 1$ the number of teachers was decreased, due to retirement, by $7 \%$ (ELSTAT: Hellenic Statistical Authority, 2015), there was an increasing trend in teachers' leaving the education system, which seems to be associated with the effort to safeguard better pension earnings. However, high cuts in pensions have led to a substantial reduction of pension claims.

\section{Theoretical Framework/Literature Review}

"Teachers vacation is associated with a strong sense of professional goals and purposes, persistence, professional aspirations, achievement and motivation the essential qualities that Bernad (1995) has observed in resilience" (in: Gu \& Day, 2007: p. 1311).

To some extent strengthening resilience concerns not only new teachers (Castro et al., 2010) or the efficiency of the education (Gu \& Day, 2007) but also those teachers who become vulnerable due to the conditions of economic crisis. For this reason, the research data can help in formulating interventions and strategies aiming to strengthen teachers' resilience, designing interventions in the mental health sector as well as in designing and implementing forms of educational and social policy, thus improving the education provided (Luthar \& Cicchetti, 2000). 
Resilience is a quite complex conceptual construct (Peng, 1994), the signification of which varies in each scientific field. For this reason, there is not a complete and coherent conceptual definition of the concept, but alternative wordings in various studies are suggested where appropriate (González-Arratia et al., 2011). Moreover, resilience "may be defined differently in the context of individuals, families, organizations, societies, and cultures” (Southwick et al., 2014: p. 1).

Due to the fact that resilience is a concept that depends on many factors and is determined in various ways, its conceptual understanding is thus difficult (Kolar, 2011). Resilience "is not homogenous" as a concept (Vinaccia et al., 2007: p. 144), "is confused with other concepts" (Pina Lopez, 2015: p. 751), and is used either in many ways (Fernandes de Araújo \& Bermúdez, 2015) or as equivalent to/synonymous with other conceptual constructs of psychology, some of which are considered as its constituent elements in some studies (Becoña, 2006).

To the American Psychological Association (2014, p. 1), resilience is understood as:

"the process of adapting well in the face of adversity, trauma, tragedy, threats or even significant sources of stress-such as family and relationships problems, serious health problems, or workplace and financial stressors. It means 'bouncing back from difficult experiences"'

Rirkin and Hooperman (1991) define resilience as a person's ability, on the one hand, to overcome adversity and, on the other hand, to develop social, academic and professional competence, despite stressful situations s/he has been experiencing. It could be considered that this definition is much closer to the identification of teachers' resilience.

Some researchers approach resilience as a static concept, as a static feature (Glantz \& Sloboda, 1999), whereas some others perceive it as dynamic process (Egeland et al., 1993; Cicchetti \& Rogosh, 1997; Ungar, 2008; Fletcher \& Sarkar, 2013).

Exploring ways how people overcome adversity, Higgins (1994) describes resilience as a process of personal rehabilitation and development. Wolin \& Wolin (1993) define resilience as one's ability to reduce negative behaviors that come from stress, withstand and to reconstruct oneself. Luther \& Cicchetti (2000) argue that resilience is explained as part of a two-dimensional framework of exposure to adversity and positive adaptation to it.

In their research, Betlman et al., (2011, p. 9) draw up a list of the following definitions for teachers' resilience: (1)“a quality that enables teachers to maintain their commitment to teaching and their teaching practices despite challenging conditions and recurring setbacks" (Brunetti, 2006: p. 813); (2) "capacity to overcome personal vulnerabilities and environmental stressors, to be able to 'bounce back' in the face of potential risks, and to maintain well-being" (Oswald et al., 2003: p. 50); (3) "using energy productively to achieve school goals in the face of adverse conditions" (Patterson et al., 2004: p. 3); (4) "capacity" to continue to "bounce back", to recover strengths or spirit quickly and efficiently in 
face of adversity and a dynamic construct subject to influence by environmental, work-specific and personal contexts" (Sammons et al., 2007: p. 694); and (5) "a mode of interacting with events in the environment that is activated and nurtured in times of stress" (Tait, 2008: p. 58).

"Masten (1994) explains that resilience must be viewed as an interplay between certain features of the individual and the broader environment, a balance between stress and the ability to cope with it, and a dynamic and developmental process that is important at life transitions"(in Santos, 2012: p. 5). In the literature of social work, resilience is characterized as a multidimensional and multi-determined dynamic process within a social system of interrelationships (Bernard, 1991; 1995; Gordon, 1995; Henderson \& Milstein, 1996; Luthar et al., 2000; Richardson et al., 1990; Walsh, 1998). "Debate as to whether or not resilience is an innate quality or dynamic process is evident in the literature" (in Santos, 2012: p. 5).

Other researchers have been involved with exploring resilient people's features and have found that resilient people's features are: insight, independence, sociability, initiative, creativity, humor morality (Wolin \& Wolin, 1993), self-efficacy (Day, 2008; Kitching et al., 2009; Chan, 2008; Tschannen-Moran \& Woolfolk Hoy, 2007; Tsouloupas et al., 2010; Woolfolk Hoy \& Burke Spero, 2005), (in: Beltman et al., 2011: pp. 15-16). Furthermore, it seems that confidence and coping strategies are important for people to overcome challenging situations or recurring setbacks (Castro et al., 2010).

Gu \& Day (2007: p. 1312) mention: “... the development of teachers' selfefficacy consistently interacts with the growth of their resilient qualities. It is by nature a dynamic, developmental process - the key characteristic of resilience".

Howard and Johnson (2004) have found that resilient teachers have: a strong sense that they could control any situation; a tendency not to dwell on past mistakes or failures in an agonizing fashion; a capacity to depersonalize unpleasant experiences and thus to understand them analytically; adaptation competence; a strong moral sense of purpose and strong support groups, including colleagues and administrators who value their efforts.

Stanford (2001) has concluded that the resistant teacher draws satisfaction from his/her work and the support from his/her colleagues, family, friends and the church. Studying 12 experienced teachers, Williams (2003) has found that are strengthened with the pleasure they get from teaching and seeking continuous self-improvement and professional development. Brunetti (2006) confirms the importance of job satisfaction and adds professional commitment.

Sammons et al., (2007) claim that mutually supportive personal, professional and peer relationships are important for resilience's dynamic process (in Beltman et al., 2011: p. 8). Finally, Greenfield (2015), through research and literature review, has inferred that resilience is connected with: support from colleagues, strong and supporting leadership, support from family and friends, student-teacher relationship, sense of purpose, hope, self-efficacy, problem-solving competence, reflection and reframing, professional development, stress relief 
and "stressors", which include poor student attitude, high workload whilst one is able to maintain a healthy work/life balance, abusive parents and poor relationships with students, colleagues or school leader.

In general terms, most definitions used in the literature are very similar (Wagnild, 2016; Henderson \& Milstein, 1996), since they refer to a person's ability to cope with adversity faced and lend to resilience fundamental common features which are: adaption, balance, competence, determination, optimism, and acceptance. "More recently, the definition has been expanded to include response to psychological stress and psychological allostasis (achieving stability through psychological or behavior change"', (Wagnild, 2016: p. 11).

In addition to the aforementioned, Richardson (2002) has explained that a new wave of research has begun to integrate personal and environmental components of resilience by examining resilience in an interdisciplinary manner. Resilience is now being studied psychologically, biologically, and socially, and involves the interaction of individual and environmental features (Almedom \& Glandon, 2007; Kim-Cohen, 2007; Smolka et al., 2007).

Social Pedagogy connects resilience with the presence of some people in one's environment whom one feels that one can address and get support, as well as with the presence of self-esteem, communication skills; one's ability to take risks and whether or not one feels empowered, that is, one experiences a sense of control over one's life, feels involved in decisions affecting him/her, and is able to take responsibility for one's own well-being and happiness, as well as one's relationships with the others (Eichsteller \& Holthoff, 2011; Petrie, 2011; Werner, 2006).

The international literature and research review on resilience shows that most research on teachers' resilience are quantitative (Beltman et al., 2011), and that a limited number of investigations concerns primary school teachers. In Greece Kaldi (2009) has conducted a research on primary school teachers' self-competence and stress as seen by undergraduate students. In an interesting research, Jarzabkowski (2002) had been studying the social dimensions of camaraderie between primary school teachers in a primary school in Australia for about a year. Jarzabkowski underlines the value of collaboration between teachers and that of colleague relations, which, as dimensions, are directly related to teachers' resilience. In one of their research in Ireland, Morgan et al. (2010) have found that positive experiences and events in teachers' professional lives work as compensation for negative ones, thus reinforcing their self-efficacy (self-efficacy).

Generally, the research data on teachers' resilience refer to the features of resilient teachers and individual school, family and social factors that influence it.

The research on teachers' resilience at this stage focuses, on the one hand, on investigating the interaction between the individual and his/her environment and, on the other hand, on risk and protective factors (Werner, 1993; Henderson \& Milstein, 1996; Werner \& Smith, 1992; Milstein \& Herry, 2000; Bernard, 2004; Waxman et al., 2004).

The present research and study aims to assess primary school teachers' resi- 
lience in Athens, which is the capital of Greece, in conditions of economic crisis. The research examines whether teachers' resilience is affected by certain parameters related to the economic crisis, such as their ability to meet their financial needs and obligations, their relationship with their colleagues, their relationship with their family members, the operation of the education system and the daily routine.

\section{Research Background}

\subsection{Economic Crisis}

Economic crisis is a phenomenon in which an economy is characterized by a sustained and significant reduction of economic activities.

"Nowadays, we are experiencing increasing uncertainty and insecurity, which are continuously being compounded by globalisation and economic crisis. The recent crisis commenced around the globe in 2008, and since then it has hit Eurozone countries, primarily those in Southern Europe. When compared with other countries (Chomsky, 2012), Greece has been affected the most by this crisis" (Mylonakou-Keke, 2015c: p. 6).

Since 2010 Greece has been depressed and has been implementing austerity memoranda that have had financial, social, occupational and psychological effects on its citizens and, of course, on teachers too. Adverse economic conditions have significantly increased hardships that teachers face either in their everyday life or at work. Because these factors play an important role both in learning process and in providing quality education, there has been shown scientific interest in measuring teachers' resilience, starting with those who teach in primary schools.

\subsection{Economic Consequences}

From the research income and living conditions of households conducted by the Greek Statistical Authority (2015), concerning 2014 income, it is shown that $35.7 \%$ of the Greek population is at risk of poverty and social exclusion and that $21.4 \%$ are under the poverty threshold.

Poverty, social exclusion, unemployment, income inequality, food insecurity and malnutrition have increased significantly with the result that more and more people have problems and experience stress. The main economic impact of the crisis on teachers at individual level is the reduction of their salaries. Salary reduction makes difficult (for teachers) to meet financial needs and obligations and make changes in lifestyle, thus making everyday life harder and harder. Lack of money to cover financial needs and obligations makes people face difficulties and adversity and fills them with anxiety.

Resilience is a very important factor associated with facing strains and stress (Rutter, 1985; Charney, 2004; Cicchetti, 2010; Wu et al., 2013). The literature refers (Fallon \& Lukas, 2002; O’Neill \& Xiao, 2012) to two main effects of the economic crisis on individuals and, by extension, on teachers, which are: i) difficul- 
ty to meet their financial needs and obligations; and ii) the change in lifestyle and in their daily lives. Given the economic crisis that Greece has been facing, our research effort has focused on teachers' resilience and has investigated its association with the economic crisis.

\subsection{Social Consequences}

The economic crisis has had effects on all sectors of social life. More specifically, it has got serious impact on public health, the increase of mental disorders, mortality and suicides, social inequality and the violation of social rights, thus affecting more socially vulnerable groups.

In our research we limited to investigate the social consequences of the economic crisis on relations between teachers and their colleagues and between teachers and members of their family. We spend the largest percentage of our daily lives with our family and colleagues. Research has shown (Kneale et al., 2014; Morin \& Kochhar, 2010) that the economic crisis affects our relationships with others. Unemployment, reduced incomes, people's difficulty to meet their financial obligations and, generally, the professional and economic instability affect the psychological state and family relations of people. People feel insecure, frustrated, resentful and angry, experience stress and often have negative mood, and all these are reflected in their interpersonal relationships.

In many cases, the economic crisis may intensify rivalry and conflict, incomprehension, mental disorders, violence and problematic behaviours within the family and at the workplace. Research has shown (Walsh, 2007; Black \& Lobo, 2008; McCann et al., 2013) that individuals' good relations with members of their family, and their colleagues are protective factors of resilience. With this in mind, we tried to investigate whether collegial and family relations, affected by the economic crisis, are associated with teachers' resilience.

\subsection{Professional Implications for the Teacher}

Over the past 15 years researchers' interest has been focused on research of teachers' resilience especially in primary and secondary education. Teaching is a demanding and stressful process during which there is often much of adversity that the teacher should handle.

Initially research was carried out by the fact that in Western societies a considerable proportion of teachers leave education in the early years of their career due to the adversity they encounter (Le Cornu, 2013; Day \& Gu, 2010; Ewing \& Smith, 2003). From research on resilience that has focused on "teacher attrition", it is shown that the main difficulties that teachers face in their work are: low self-esteem (Day, 2008), difficulties to seek help (Fantilli \& McDougall, 2009; Flores, 2006; Jenkins et al., 2009), conflict between personal beliefs and practices being used (Flores, 2006; McCormack \& Gore, 2008; Beltman et al., 2011). Moreover, continuous government policy reforms increase the pressure on teachers as well as their workload (Gu \& Day, 2007). Educational reforms, at least temporarily, disturb the relative stability of teachers' work (Bottery, 2005; 
Goodson \& Hargreaves, 1996; Helsby, 1999; Sacks 2004).

Nevertheless, the Greek reality, due to the economic crisis, is different. Teachers do not leave education, despite the fact that they face many difficulties, since they don't have many job choices and-if they abandon it, they will lead to unemployment. Moreover, due to the limitation of recruitment in recent years (as resulted from the economic crisis), it is observed that the majority of teachers are over 20 years of service. Aaronson (2008), Chevalier \& Dalton (2004), Grissmer \& Kirby (1987), Guttman (2001), Matheson (2007), OECD (2005) indicate that there is an urgent need to investigate how socio-cultural and political challenges affect teachers' personal, interpersonal and school conditions at work and their life, since it seems that the majority of teachers who have experience over 20 years in many countries cannot change their career for economic and domestic reasons.

The economic crisis in Greece has created economic and social problems, and has a negative impact on the quality of education. Access to education is not easy in cases where students live in geographically isolated areas or in areas with low population density. Both education and the school have been negatively influenced, as public spending has been cut, teaching staff has been reduced, and there has been an increase in the number of students in classrooms. During the period 2009/10-2012/13 the primary school units were reduced by $13.5 \%$ (ELSTAT, 2015). Schools units, educational services, health and welfare services have been eliminated or merged, thus burdening not only teachers' poor working conditions but also the living conditions of students and their families. Students and their families encounter the specter of poverty, and there is an increase in povertization. Primary school teachers, as members of the Greek society, are also affected by the crisis, face problems in their teaching, due to the substantial reduction in resources for Education and, they witness both their pupils' malnutrition and the economic problems that their pupils and their families face.

Moreover, due to austerity measures, "teachers are forced to contend with frequent and prescriptive government reforms, outcome-driven methods and high levels of accountability, and as result many have been left feeling overworked, undervalued and professionally marginalized" (Priestley et al., 2012, in: Greenfield, 2015: p. 52). Teaching is increasingly recognized as a "high stress" profession (Galton \& McBeath, 2008; Kyriacou, 2000; Pricewaterhouse Coopers, 2001). On the one hand, whereas the school strives to fulfill its mission under circumstances of an ever worsening economic and social crisis that causes social inequalities and burdens the teacher's work, on the other hand, the economic crisis limits the role of education as a lever for social development and economic growth (Hanushek \& Wößmann, 2007).

Furthermore, due to the crisis, there has been a change in labour relations. Lots of teachers are forced to teach in two or three schools in order to fill their teaching schedule. Last years, due to the fact that the recruitment of permanent staff has been frozen, gaps in human resources have been covered by teachers 
with no permanent employment relationship (that is, substitute teachers). The majority of teachers with a few years of experience work with flexible employment relationships.

Luthar et al., (2000) mention that resilience is a dynamic process during which the individual tries to adapt positively to significant adversity s/he encounters. Therefore, mental toughness or psychological resilience is one of the most important skills that teachers need to develop if they are to successfully cope with daily challenges.

\subsection{The Necessity of Research}

Henderson \& Milstein (1996) claim that if teachers do not have resilience, it is unrealistic to expect students to be resilient. Teachers' role in learning process is important and is related to the quality of education provided. "Teacher's work is becoming increasingly intensified with teachers expected to respond to greater pressures and comply with multiplying innovations under conditions that are at best stable and at worst deteriorating" (Hargreaves, 1994, 2000, 2003, in Gu \& Day, 2007: p. 1303). Moreover, the economic crisis has reduced both their income and expenditures on education. Thus, the economic crisis has exacerbated teacher's stress, which may have a great impact on teacher's effectiveness (Howard \& Johnson, 2004), working relationships (Kyriacou, 1987; Le Cornn, 2009, 2013; Papatraianou \& Le Cornn, 2014; Gu \& Day 2013) and teacher's resilience (Greenfield, 2015; Bobek, 2002). Having analyzed the VITAE $^{1}$ research, Gu \& Day (2007: p. 1306) have found that "resilience depends on three parameters: the personal (related to their lives outside school); the situated (related to their lives in school); and the professional (related to their lives values, beliefs in the interaction between these and external policy agendas)". Therefore, resilience is of great importance for the quality of education provided and its reinforcement through educational and training interventions is a challenge.

Thus, it is shown the research on level of teachers' resilience in times of economic crisis is necessary as well as the investigation as to whether some parameters of economic crisis have an impact on it. Our research aims, first, to measure the level of teachers' resilience and, second, to investigate if the following parameters are associated with the economic crisis: (i) teachers' ability to meet their financial needs and obligations; (ii) teachers' good relations with their colleagues; (iii) teachers' good relations with members of their family; (vi) the ability of the education system to meet teachers' needs; and (v) difficulties that teachers face in their daily lives that affect or they don't their resilience.

The elements of originality of our research efforts lie in the fact that they illustrate teachers' level of resilience in urban area of Athens, plagued by the economic crisis, and that this research can be a reference point to and a benchmark for comparison with relevant researches on conditions of economic crisis or not.

1The VITAE research, "Variations in Teachers' Work, Lives and Effectiveness" was a mixed method, four-year longitudinal study conducted in England with 300 teachers in 100 schools across seven local Authorities, funded by the Department for Education and Skills (DfES). 
International literature has shown that similar research has never been conducted in the past, that is, research with the specific focus on possible correlation between teachers' resilience and economic crisis. From a scientific point of view, our research contributes to challenging to whether austerity measures that have been generally imposed on the European Union and, more particularly on Greece, affects teachers' resilience and thus the quality of education provided.

\section{The Research}

It was decided that research should be carried out in Athens, the capital of Greece, which is the largest urban centre in the country, since life and teaching in urban centres is more difficult than in suburban and rural ones (Patterson et al., 2004; Sachs, 2004). In urban centres teachers are responsible for lots of students in the class and correspondingly for many families with different needs (Darling-Hammond, 2003), with the result that they have to deal with more problems and difficulties. Moreover, the economic crisis has particularly affected the urban centers, where the effects are stronger and more visible in residents' lives, thus affecting daily lives of teachers, students and their families.

\subsection{Research Aim, Objectives and Hypotheses}

Taking into consideration the literature review on and the aforementioned arguments about resilience issues, this research aims to: assess the level of primary school teachers' resilience during the time of economic crisis and investigate whether particular effects of the economic crisis are associated with the teacher's resilience. Furthermore, the objective of the present research has been to investigate whether the relationships that a primary school teacher develops with his/her family and his/her colleagues may affect his/her resilience.

Given that the effects of the economic crisis are multidimensional and multileveled, we have narrowed down the scope of the research to the following research hypotheses:

1) Primary school teachers' resilience in the urban area of Athens is moderate to low.

2) There is a positive correlation between primary school teachers' resilience in the urban area of Athens and their ability to meet their financial needs and obligations;

3) There is a positive correlation between primary school teachers' resilience in the urban area of Athens and the good relations they develop with their colleagues;

4) There is a positive correlation between primary school teachers' resilience in the urban area of Athens and the good relations they develop with the members of their family;

5) There is a positive correlation between primary school teachers' resilience in the urban area of Athens and the ability of the education system to meet their educational needs; and

6) There is a negative correlation between primary school teachers' resilience in 
the urban area of Athens and the difficulties they face in their daily lives due to the economic crisis.

7) There is no difference in teachers' resilience in relation to gender, age, years of service and responsibility positions.

\subsection{Research Methodology}

\subsubsection{Participants: Demographic and Social Features of the Sample}

In the research there were involved 568 primary school teachers working in public primary schools in the urban area of Athens. Of them 156 were male teachers, 412 female teachers and specialist teachers. Teachers that are responsible for a single class (class teachers) were $78.3 \%$, whereas $7.7 \%$ were foreign language teachers, $4.6 \%$ were physical education teachers and the remaining $9.4 \%$ was of other specialties (art courses, music, theater studies and ICT), while position of responsibility (school masters) was $12.7 \%$.

The distribution of the questionnaires regarding the teacher's sex was: $27.5 \%$ men and $72.5 \%$ women. A large percentage preponderance of women in primary teachers is a feature of the population of teachers in Greece.

As far as age is concerned, the majority is between 45 and 60 years. Regarding working experience, the structure of the sample in relation to the years of service in primary education was as follows: $40.7 \%$ of the sample has experience of 20 to 29 years, and $34.7 \%$ has experience of 10 to 19 . Teachers who have with (little) experience of 1 to 9 years and are over 30 years are less represented in the sample and are collectively represent $24.6 \%$ of the sample.

Regarding the marital status of respondents, more than half $(53.5 \%)$ is married with children.

As far as their qualification is concerned, $21.3 \%$ of the teachers surveyed have a postgraduate or doctoral degree in addition to their first University degree (i.e. Bachelor's degree).

\subsubsection{Research Tools}

Resilience was measured using the Wagnild and Young (1993) Resilience Scale (RS). The scale is a self-report questionnaire consisting of 25 items. Responses are recorded on a seven point Likert scale ranging from "1" (Strongly Disagree) to "7" (Strongly Agree). It should be clarified that the Total RS score is generated if we sum the responses of statistical units in the sample of 25 questions with the result that the value is formed with a minimum of 25 and maximum of 175 (Wagnild, 2016). Higher scores indicate greater resilience.

For the needs of the research we combined [RS_25 (25 questions)] with socio-demographic data and 5 items that are positively related. Responses are recorded on a seven point Likert scale ranging from "1" (Strongly Disagree) to "7" (Strongly Agree).

In our research five additional variables were used so that teachers' resilience, adapted to the Greek reality, as well as their relationship with family members, colleagues and as to whether their needs are satisfied by the education system are measured. 
In our research, five more variables were used to measuring teachers' resilience, adapted to the Greek reality, as well as their relationships with family members, colleagues and the satisfaction of the needs with the education system. 1) I cope and meet my financial needs and obligations during the economic crisis.

2) My relationship with my colleagues is excellent.

3) My relationship with my family members is excellent.

4) The operation of the Education System covers satisfactorily my professional needs, during this time of crisis.

5) The economic crisis complicates significantly my daily life.

The construction of these variables resulted from the need to measure teachers' resilience vis-à-vis the economic, social and professional impact of the crisis of recent years on their lives. Due to these consequences, adversity that teachers faced by teachers; and since resilience is defined as the ability to adapt and overcome adversity (Garmezy, 1974; Masten, Best, \& Gamezy, 1990), their use was deemed necessary to the teachers of our country

\subsubsection{Statistical Data Analysis and Results}

Research data processing was performed according to the following analyses:

A) First of all, we used descriptive statistics to check the data distribution with percentage frequency indices.

We will mention some indicative results for teachers' answers to statements with which they absolutely agree, in a high percentage.

A very high percentage of teachers responded that they agree with the following statements very much (at a rate more than $70 \%$ ):

"Keeping interested in things is important to me"

"I can be on my own if I have to"

"I feel proud that I have accomplished things to my life"

"I keep interested in things"

"In an emergency, I am someone people generally can rely on

"My life has meaning"

"My relationship with my colleagues is excellent"

"My relationship with my family members excellent"

A very high percentage of teachers responded that they agree with the following statements very much (at a rate of $60 \%-70 \%$ )

"When I make plans I follow through with them"

"I usually manage one way or another"

"I usually take things in stride"

"I am friends with myself"

"I can get through difficult times, because I've experienced difficulty before"

"I can usually find something to laugh about"

"My belief in myself gets me through hard times"

"I can usually look at a situation in a number of ways" 
"I have enough energy to do what I have to do"

(see below; 5. Discussion)

B) Then, to measure the differences between means' difference the following indicators were used: a) independent samples t-tests; and b) analysis of variance (ANOVA) level of significance $5 \%$.

According to the Model of Resilience of Wagnild and Young (Wagnild, 2016), the minimum value of resilience is 25 (weak resilience) and the maximum one is 175 (strong resilience). The same scholars give Resilience Scale scores, as it becomes conspicuous from the answers to the 25 questions of the questionnaire: 25 - 100: very low, 101 - 115: low, 116 - 130: on the low end, 131 - 145: moderate, 146 - 160: moderately high, 161 - 175: high. Table 1 presents the results of our research, according to this scale.

In our research, it has been found that a percentage $(34 \%+17.1 \%) 51.1 \%$ of teachers who answered the questionnaire is of moderately high and high resilience. Cumulatively, $77.7 \%$ of teachers in the present research are of moderate and above moderate to high resilience. Only a very small percentage $(7.6 \%)$ is of very low and low resilience. Cumulatively, $22.2 \%$ of primary school teachers of the research sample are of very low up to on the low end resilience. Thus, Research Hypothesis [i] is rejected.

C) Then, we proceeded to independent sample t-test between different categories of the sample, and we had the following statistically significant differences (5\% significance level).

- Female teachers have higher resilience than their male counterparts.

- Teacher who are in the age group of above 45 years are more resilient than those who are under 45 years. In fact, teacher older than 60 years have high level of resilience.

- Teachers who are in over 29 years of service show more resilient than those who are in less than 20 years in service.

- Teachers with responsibility position (headmasters, assistant headmasters) have higher resilience than other teachers who have no position of responsibility. Thus, Research Hypothesis [vii] is rejected.

Table 1. Total RS_25 scores.

\begin{tabular}{cccccc}
\hline & Frequency & Percent & Valid Percent & Cumulative Percent \\
\hline Valid & $25-100$ [very low] & 18 & 3.2 & 3.2 & 3.2 \\
$101-115$ [low] & 25 & 4.4 & 4.4 & 7.6 \\
$116-130$ [on the low end] & 83 & 14.6 & 14.6 & 22.2 \\
$131-145$ [moderate] & 151 & 26.6 & 26.6 & 48.8 \\
$146-160$ [moderately high] & 193 & 34.0 & 34.0 & 82.7 \\
$161-175$ [high] & 97 & 17.1 & 17.1 & 100.0 \\
Total & 567 & 99.8 & 100.0 & \\
Missing System & 1 & 0.2 & & \\
Total & 568 & 100.0 & &
\end{tabular}


There has been no statistically significant difference between teachers who work in schools where 25 teachers work and those who work in high-capacity schools (where 26 teachers and more work), despite the fact that in our sample, slightly higher moderate resilience was presented by the group of teachers who serve/work in high-capacity schools, but without statistical significance.

D) The internal consistency of the questionnaire was analyzed using Cronbach's alpha. The Cronbach's alpha is 0.907 (Table 2) that shows the high internal consistency of the questionnaire and the reliability of this research.

The next statistical analysis we did was to perform correlation test between our own research data and the two major factors named Personal Competence and Acceptance of self and life, which Wagnild and Young have highlighted in their own research (in: Wagnild, 2016). The test was performed with Pearson's correlation coefficient and statistically significant correlations were found (Table 3).

The factor Personal Competence showed very high positive correlation (0.964) with the overall resilience (Total RS_25 Score), whereas the factor Acceptance of self and life showed a high positive correlation (0.778) with the overall resilience (Total RS_25 Score). All calculations were made at $1 \%$ significance level. Moreover, the high positive correlation between the factors Personal Competence and Acceptance of self and life is noteworthy (0.708).

E) Then, Correlation Analysis with Pearson coefficient was made to correlate the RS_25 total score of 25 questions with the RS_30, resulting from grading all 30 questions of the questionnaire with reversed question 30 (which describes a positive state). In essence, the values of 5 additional questions were added to the original questionnaire, which we included in it and were related to the influence of the economic crisis and teachers' relationships (with the family, at school); see Table 4.

Table 2. Reliability statistics.

\begin{tabular}{ccc}
\hline Cronbach's Alpha & Cronbach's Alpha Based on Standardized Items & N of Items \\
\hline 0.907 & 0.919 & 25 \\
\hline
\end{tabular}

Table 3. Correlations.

\begin{tabular}{ccccc}
\hline & & $\begin{array}{c}\text { Personal } \\
\text { Competence }\end{array}$ & $\begin{array}{c}\text { Acceptance } \\
\text { of self and life }\end{array}$ & $\begin{array}{c}\text { Total } \\
\text { RS score }\end{array}$ \\
\hline Personal Competence & Pearson Correlation & 1 & $0.608^{* *}$ & $0.964^{* *}$ \\
Acceptance of self and life & Pearson Correlation & $0.608^{* *}$ & 567 & 567 \\
& $\mathrm{~N}$ & 567 & $5678^{* *}$ & 567 \\
Total RS score & Pearson Correlation & $0.964^{* *}$ & $0.778^{* *}$ & 1 \\
& $\mathrm{~N}$ & 567 & 567 & 567 \\
\hline
\end{tabular}

${ }^{* *}$ Correlation is significant at the 0.01 level (2-tailed). 
Table 4. Correlation analysis between total RS_25 and total RS_30.

\begin{tabular}{cccc}
\hline & & TOTAL_RS_25 & TOTAL_RS_25 \\
\hline TOTAL_RS_25 & Pearson Correlation & 1 & $0.985^{* *}$ \\
TOTAL_RS_30 & Pearson Correlation & $0.985^{* *}$ & 567 \\
& & 567 & 1 \\
${ }^{* *}$ Correlation is significant at the 0.01 level (2-tailed). &
\end{tabular}

There has been an extremely high correlation of Total RS_25 to Total RS_30 at a level of statistical significance of $1 \%$ which is 0.985 .

So, with the 5 additional questions the correlation changes neither its direction nor its size, whereas we have incorporated variables related to relationships concerning satisfaction with the professional system and the consequences of the economic crisis.

F) The subsequent statistical analyses we made was to check the correlation test using Pearson's correlation coefficient so to: a) correlate teachers' resilience (Total RS_25 Score) to each of the five questions (26 - 30), which we had added to the questionnaire; and $b$ ) to relate each question from the additional ones (26 - 30) to the sum of the remaining 29 questions of the questionnaire (total RS_29 Score). All calculations were made at $1 \%$ significance level.

There have been found statistically significant correlations. More specifically, a high positive correlation (0.793) has been shown by teacher's resilience (RS_25) in Question 28: "My relationship with my family members is excellent", and the specific question has shown a high positive correlation (0.836) to the sum of the remaining 29 questions (Total RS_29 [-28] Score).

Furthermore, high correlation (0.761) has been shown by resilience (RS_25) in Question 27: "My relationship with my colleagues is excellent"; high correlation (0.751) has been shown by teacher's resilience (RS_25) in Question 28: "My relationship with my family members is excellent" and the same question has shown high correlation (0.803) to the sum of the remaining 29 questions (total RS_29 [-27] Score).

As far as the other three questions (26. 29 and 30) are concerned, a moderate correlation to RS25 has been found. More specifically: RS25 and Q26: 0.680, (I cope and cover my economic needs and obligations during the economic crisis), RS25 and Q29: 0.394 (the operation of the Education System covers satisfactorily my professional needs during this period of crisis) and RS25 and Q30 (reversed): 0.487 (economic crisis does not complicate significantly my daily life).

Thus, Research Hypotheses [ii], [iii], [iv], [v] and [vi] are confirmed.

G) Later, a Crosstabulation Analysis among the questions of the questionnaire was made. For example, we refer to that analysis that took place among the additional questions, such as:

a) Between Q26 and Q30: Q26 (I cope and cover my economic needs and ob- 
ligations during the economic crisis) and Q30 (the operation of the Education System covers satisfactorily my professional needs during this period of crisis). The analysis has shown that, although the economic crisis complicates significantly everyday life (at a rate of $43.8 \%$ very strongly and strongly), at the same time the teacher copes with meeting his/her financial needs and requirements at a better level (at a rate of $50.7 \%$ very strongly and strongly).

b) A Crosstabulation analysis between Q27 and Q29 was made: Q27 (My relationship with my colleagues is excellent) and Q29 (the operation of the Education System covers satisfactorily my professional needs during this period of crisis). The analysis has shown that, although teachers are dissatisfied with the operation of the education system (only $13.6 \%$ agree very strongly and $28.9 \%$ disagree very strongly and strongly), this does not affect their good relations with their colleagues (70.5\% have excellent relations).

c) A Crosstabulation analysis between Q27 and Q28 was made: Q27 (My relationship with my colleagues is excellent) and Q28 (My relationship with my family members is excellent). The analysis has shown that primary school teachers of our sample have excellent relationships with both their family (at a rate of $80.5 \%$, whereas only $1.3 \%$ disagree very strongly and strongly), and their colleagues.

\section{Discussion}

This research has shown several interesting results to be further discussed, reflected upon and utilized. The questionnaire of 30 resilience measurement scales for the Greek reality, introduces an innovation that is the use of 5 more sevenlevel scales than those proposed by Wagnild and Young (Wagnild, 2016), which measure the influence of the economic crisis on the respondent's resilience, his/her relationships (with his/her family, at school) as well as the satisfaction of his/her the needs from the education system. Similar correlations have been made with the RS health status (Wagnild, 2016).

Then, we will discuss some of the important results that have emerged from our research on teachers who live and work in the greater urban area of Attica under conditions of severe economic crisis, which has plagued Greece.

a) A first remarkable result that came out of our research is that more than over half of the teachers have moderately high and high resilience, while only a very small percentage (7.6\%) is of very low and low resilience. This seems to be associated with the excellent relationships that teachers have established with the members of their family educators and their colleagues (see below).

b) A very high percentage of teachers of the sample has very high values in features associated with the continuing existence of interests in their life, self-efficacy, sense of achievement and pride for their achievements, their conscious objectives for which they feel effective to implement them, confidence, strength and the ability to support others, humour, excellent relationships with family and colleagues and, generally, they feel very good about themselves. Fredrickson (2004), who has developed the "broaden-and-build" theory argues that positive 
emotions fuel resilience. Moreover, school context, personal lives and relationships are associated with resilience (Le Cornu, 2009, 2013; Papatraianou \& Le Cornu, 2014).

c) The research data have shown that high resilience observed in the majority of teachers can be attributed to good relationships they have established with family members and colleagues. Family and collegial relationships seem to contribute significantly to teachers' resilience. Teachers draw strength and support from family and colleagues to overcome adversities that have increased due to the economic crisis. Resilience is defined as positive adaptation with emphasis on the individual's personal and social skills, such as academic success and healthy relationships (Ungar 2008; Ungar \& Lienbenberg, 2011). Human relationships are associated with resilience (Johnson et al., 2014). Judgment and recognition by "significant others" have important influence on teachers' sense of resilience (Luthar \& Brown, 2007: p. 941; Day et al., 2006; Day \& Gu, 2010). Day \& Gu (2010), and Howard \& Johnson (2004) argue that there is a link between resilience and relationships with family members.

d) The economic crisis has moderately affected teachers' resilience. All these occur simultaneously with the fact that they state moderately that the economic crisis makes difficult their daily life and their ability to respond to meet their financial needs and obligations is also moderate (but at a somewhat better level). Day et al. (2006) and Peterson et al. (2008) also found that socio-economically challenging circumstances affect resilience. The vast majority of teachers in our research are permanent civil servants, so they do not face the problem of unemployment, and wage cuts they have been subjected to have shown that they have not complicate significantly their daily lives.

e) As far as professional issues are concerned, most teachers in our research express their discomfort for the operation of the education system, which does not cover their professional needs satisfactorily during the economic crisis, but this does not affect the excellent relationships the teachers have established with colleagues. Day \& Gu (2010) found that teachers consider relationships in the work environment as the most important factor that helps them maintain their resilience. According to other studies, the challenges teachers face in their work are: low salaries, inadequate support from the school administration, students' behavioral problems and their being continuously overloaded with additional responsibilities (Gu \& Day, 2007; Le Cornu, 2009; MCEETYA, 2004; Parker \& Martin, 2009). Personal features and positive influence of the social milieu in which the person lives and works, independently or together, interact and contribute to building resilience (Rutter, 2006; Zucker, 2006). Other researchers (Jarzabkowski, 2002; McCormack \& Gore, 2008; Schlichte, Yssel \& Merbler, 2005, Beltman et al., 2011; Day \& Gu, 2010) argue that there is link between resilience and relationship with administrators and colleagues. Anderson and Olsen (2006) suggested that good relations with colleagues help face problems. Colleagues could boost morale (Howard \& Johnson, 2004) and others' positive outlook could be contagious (Jarzabkowski, 2002). Sammons et al. (2007) claim that 
labour relations help in teachers' adaptation, Brunetti (2006) states that they help teachers feel being satisfied with their job and being committed to their profession, and Papatraianou \& Le Cornu (2014) argue that labour relations play a principal role in the development of resilience. In their analyses, Gu \& Day (2013) observed that in school environments that there was a lack of support from colleagues and leadership $44 \%$ of the teachers who were in the last stage of their careers reported lack of sense of resilience. "Schufeli and Bakker (2004), also, found the obverse, that a lack of social support from colleagues cold lead to teachers' emotional exhaustion and depersonalization" (Gu \& Day, 2013: p. 37). Generally, it has been pointed out by many scholars the contribution of positive professional relationships to resilience (Seligman \& Csikszentmihalyi, 2000; Masten, 2001; Gorman, 2005; Luthans et al., 2007). "Luthar (2006) suggests that Resilience rests, fundamentally, on relationships" in: Gu \& Day, 2013: p. 36). Resilience helps teachers create healthy learning environment, using support networks (Le Cornu, 2009).

Teachers who work in environments that promote specific protective factors such as: positive connections; life-guiding skills; nurture and support; purpose and explanations; meaningful participation; and clear and consistent boundaries (Henderson \& Milstein, 1996) are more resilient (Benard, 2004). "The capacity to be resilient in different negative circumstances, whether these are connected to personal or professional factors can be enhanced or inhibited by the nature of the settings in which we work the people with whom we work and the strength of our belief and aspiration" (Benard, 1991; Day et al., 2006; Henderson \& Milstein, 1996; Luthar, 1996; Oswald, Johnson, \& Howard, 2003, in Gu \& Day, 2007: p. 1305). Elements from the teacher's professional environment that can negatively affect his/her resilience is when the teacher works in low-income schools, has fewer resources, poor working conditions, and the added stress of serving large numbers of high need students and their parents (Darling-Hammond \& Snyder, 2000). The pressure that the teacher can feel from some parents is actually an aggravating factor, whereas the aid the parents offer to the teacher is a very important supportive factor.

A relevant result has come out of research projects carried out in Greece during the economic crisis, addressing prevention and tackling antisocial behavior in the school community. These programs have shown that it is effective the utilization of Syneducation ${ }^{2}$ (synergy + education) Model (interactive and cooperative education students, parents and teachers). The Syneducation Model, among others, interactively connects students' resilience to that of teachers, parents and other adult stakeholders. More specifically, it has been shown that, despite the difference in age, children's resilience through mutual mentoring, is fed and simultaneously feeds that of adults (Mylonakou-Keke, 2015a, 2015b).

${ }^{2}$ Syneducation (synergy + education) is defined as a shared educational experience that is acquired simultaneously and in collaboration by people of different ages (pupils, parents, other members of the pupils' family, educators, school administrators, representatives of the local community, policy makers etc.), different knowledge, experiences, interests and/or different social cultural backgrounds (Kekes \& Mylonakou, 2006; Mylonakou \& Kekes, 2005, 2007). 
f) Older and with more years of service teachers predominate in resilience. In a sample of the general population Wagnild (2016) found that resilience increases with age. Carroll \& Foster (2010) document the positive role the experience plays on job performance and satisfaction. Lots of researchers link resilience with self-efficacy (Gibson \& Demdo, 1984; Rutter, 1990; Gu \& Day, 2007), so we could assume that older and more experienced teachers, because of their experience they have high self-efficacy, hence high resilience. While Bobek (2002, p. 202) noted that: "A teacher's resilience is enhanced when he is capable of assessing adverse situations, recognizing options for coping, and arriving at appropriate solutions" (also see Gu \& Day, 2007; Benard, 1991; Henderson \& Milstein, 1996; Oswald et al., 2003; Pence, 1998; Rutter et al., 1979; Wang et al., 1993). So it can be presumed that older and more experienced teachers, because they have faced much more adversity and difficulties have strengthened their resilience. In contrast, Gu \& Day (2013) argue that young teachers and teachers in the middle stage of their careers are likely to maintain more their sense of resilience than experienced teachers, because over time resilience is reduced due to continuous changes in government policies, students' behaviour problems, increasing bureaucracy and workload, and due to of disease burden.

g) Female teachers who participated in our research showed higher resilience than their male counterparts. In his research on of the general population Wagnild (2016, p. 52) found that RS scores between males and females were not significantly different. Possibly, this can be explained by the fact that the average Greek woman should play many roles daily and face many different problems, thus enhancing her adequacy and resilience in difficult situations

h) Teachers that have position of responsibility (school principals, school deputy principals) have higher resilience. It is speculated that this is because every day they have an increased workload and have to effectively address many problems and adversities that require resilience. This finding agrees with the results of other studies which suggest that a strong caring leadership enhances resilience (Howard \& Johnson, 2004; Goddard \& Foster, 2001; Tschannen-Moran \& Woolfolk Hoy, 2007; Beltman et al., 2011). Over time the educational literature has also been consistent in suggesting that in-school management support for teachers' learning and development, leadership trust and positive feedback from parents and pupils are key positive influences on their motivation and resilience (Huberman, 1993; Webb et al., 2004; Brunetti, 2006; Leithwood et al., 2006; Day et al., 2006; Day \& Gu, 2010; Castro et al., 2010; Meister \& Ahrens, 2011).

i) There has been found no correlation between teachers' educational level and their resilience. A possible explanation may be the fact that all teachers have a very good educational level, all have a university degree and more than $20 \%$ of the teachers in our research have a master's or a doctoral degree, and a very high percentage (94\%) of teachers systematically undergo additional trainings and programmes on education, many of which they pay by themselves. 


\section{Concluding Thoughts}

Teachers' resilience is a multidimensional concept and is influenced by individual, environmental, social, professional and economic factors. Research on resilience has been conducted in various fields and has led to a number of potential features and factors that are considered to promote or reduce resilience.

Resilience is a person's ability to positively adapt to difficulties and vicissitudes of life and to face them effectively. Austerity measures and the economic crisis in Greece have increased the difficulties and problems that teachers have been facing in their lives and at their work. Resilience is the key for the teachers to face adversity and be able to do their best in the educational process. The quality of education depends on teachers' quality and effectiveness.

Our research has found that more than half of primary school teachers who participated in it show moderately high and high resilience and the same time a very small percentage has very low and low resilience. Furthermore, the Greek teacher's resilience has been influenced by the economic crisis at a moderate level. It seems that teachers in Athens, despite the fact that they have been experiencing difficulties due to the crisis, are still facing them at a good level. An important finding is that the Greek teacher's resilience is very highly correlated to his/her relationship with his family and his/her colleagues.

The Greek teacher is supported by a strong network of relationships that s/he establishes with his/her family members and his/her colleagues. This network of relationships seems to support and strengthen the features that make up resilience. The strong family supportive nexus that is still present in Greece seems to effectively support its members, and our researches has shown that this is indeed the case and even affects the levels of teachers' resilience.

Moreover, a large percentage of teachers in the sample have very high values in attributes associated with high resilience, such as self-efficacy, targeting and its efficient implementation, the sense of achievement and pride, humour, the existence interests, the ability to support other people. It seems that the Greek teacher feels confident and proficient in his/her work and strong to face difficulties the crisis brings. This, of course, may be because of the strong network of positive relationships s/he establishes, but it may well be attributed to other factors that the present research did not investigate.

The present paper proposes a new and very interesting field for research on teachers' resilience in adverse conditions of the economic crisis, and seeks to offer valuable data both to those involved in designing education policy and to teachers themselves.

\section{Recommendations for Future Research}

The results of the present research show that research on teachers' resilience in times of economic crisis or not should continue, and the additional parameters that could not be investigated in this scientific endeavour should be further explored. A similar research to ours could be extended to teachers of secondary and higher education, too. 
Additionally, it is worth being explored whether teachers' resilience and/or specific features of it (i.e. of resilience) are associated with elements and factors from the school operation, such as school climate, the level of their communication with the students' families, their perception of how leadership is exercised (by the school principle) at school, the sense of teachers' satisfaction with their work, efficiency in their work etc.

The results of such research could contribute to shaping educational policies and supporting both the educational work and educational functions in general.

\section{References}

Aaronson, D., \& Meckel, K. (2008). The Impact of Baby Boomer Retirements on Teacher Labor Markets. Chicago Fed Letter No. 254.

https://www.chicagofed.org/publications/chicago-fed-letter/2008/september-254

Almedom, A. M., \& Glandon, D. M. (2007). Resilience Is Not the Absence of PTSD Any More than Health Is the Absence of Disease. Journal of Loss and Trauma: International Perspectives on Stress \& Coping, 12, 127-143. https://doi.org/10.1080/15325020600945962

American Psychological Association (2014). The Road to Resilience. Washington DC: American Psychological Association. http://www.apa.org/helpcenter/road-resilience.aspx

Anderson, L., \& Olsen, B. (2006). Investigating Early Career Urban Teachers' Perspectives on and Experiences in Professional Development. Journal of Teacher Education, 57, 359-377. https://doi.org/10.1177/0022487106291565

Becoña, E. (2006). Resiliencia: Definición, características y utilidaddel con-cepto. Revista de Psicopatología y PsicologíaClínica, 11, 125-146.

Beltman, S., Mansfield, C., \& Price, A. (2011). Thriving Not Just Surviving: A Review of Research on Teacher Resilience. Educational Research Review, 6, 185-207. https://doi.org/10.1016/j.edurev.2011.09.001

Bernard, B. (1991). Fostering Resiliency in Kids: Protective Factors in the Family, school, and Community. San Francisco, CA: WestEd Regional Educational Laboratory.

Bernard, B. (1995). Fostering Resilience in Children. ERIC/EECE Digest, EDO-PS-99.

Bernard, B. (2004). Resiliency: What We Have Learned. San Francisco, CA: WestEd Regional Educational Laboratory.

Black, K., \& Lobo, M. (2008). A Conceptual Review of Family Resilience Factors. Journal of Family Nursing, 14, 33-55. https://doi.org/10.1177/1074840707312237

Bobek, B. L. (2002). Teacher Resiliency. [Commentary, Qualitative Study]. The Clearing House, 75, 202-205. https://doi.org/10.1080/00098650209604932

Bottery, M. (2005). The Individualization of Consumption: A Trojan Horse in the Destruction of the Public Sector? Educational Management, Administration and Leadership, 33, 267-288. https://doi.org/10.1177/1741143205054010

Brunetti, G. J. (2006). Resilience under Fire: Perspectives on the Work of Experienced, Inner City High School Teachers in the United States. Teaching and Teacher Education, 22, 812-825. https://doi.org/10.1016/j.tate.2006.04.027

Carroll, T., \& Foster, E. (2010). Who Will Teach? Experience Matters. Washington DC: National Commission on Teaching and America's Future. http://nctaf.org/wp-content/uploads/2012/01/NCTAF-Who-Will-Teach-Experience-M atters-2010-Report.pdf 
Castro, A. J., Kelly, J., \& Shih, M. (2010). Resilience Strategies for New Teachers in High-Needs Areas. Teaching and Teacher Education, 26, 622-629. https://doi.org/10.1016/j.tate.2009.09.010

Cefai, C. (2007). Resilience for All: A Study of Classrooms as Protective Contexts. Emotional and Behaviour Difficulties, 12, 119-134. https://doi.org/10.1080/13632750701315516

Chan, D. W. (2008). Emotional Intelligence, Self-Efficacy, and Coping among Chinese Prospective and In-Service Teachers in Hong Kong. Educational Psychology, 28, 397-408. https://doi.org/10.1080/01443410701668372

Charney, D. S. (2004). Psychobiological Mechanisms of Resilience and Vulnerability: Implications for Successful Adaptation to Extreme Stress. American Journal of Psychiatry, 161, 195-216. https://doi.org/10.1176/appi.ajp.161.2.195

Chevalier, A., \& Dalton, P. (2004). Teacher Shortage: Another Impending Crisis? (pp. 15-21). CentrePiece.

Cicchetti, D. (2010). Resilience under Conditions of Extreme Stress: A Multilevel Perspective. World Psychiatry, 9, 145-154. https://doi.org/10.1002/j.2051-5545.2010.tb00297.x

Cicchetti, D., \& Rogosch, F. A. (1997). The Role of Self-Organisation in the Promotion of Resilience in Maltreated Children. Developmental Psychopathology, 9, 797-815. https://doi.org/10.1017/S0954579497001442

Darling-Hammond, L. (2003). Keeping Good Teachers: Why It Matters, What Leaders Can Do. Educational Leadership, 60, 6-13.

Darling-Hammond, L., \& Snyder, J. (2000). Authentic Assessment of Teaching in Context. Teaching and Teacher Education, 16, 523-545. https://doi.org/10.1016/S0742-051X(00)00015-9

Day, C. (2008). Committed for Life? Variations in Teachers' Work, Lives and Effectiveness. Journal of Educational Change, 9, 243-260. https://doi.org/10.1007/s10833-007-9054-6

Day, C., \& Gu, Q. (2010). The New Lives of Teachers. London: Routledge.

Day, C. W., Stobart, G., Sammons, P., Kington, A., Gu, Q., Smees, R. et al. (2006). Variations in Teachers' Work, Lives and Effectiveness. Final Report for the VITAE Project, DfES.

Doll, B., Brehm, K., \& Zucker, S. (2014). Resilient Classrooms: Creating Healthy Environments for Learning. New York: Guilford Publications.

Egeland, B., Carlson, E., \& Sroufe, L. A. (1993). Resilience as Process. Development and Psychopathology, 5, 517-528. https://doi.org/10.1017/S0954579400006131

Eichsteller, G., \& Holthoff, S. (2011). Conceptual Foundations of Social Pedagogy: A Transnational Perspective from Germany. In: C. Cameron, \& P. Moss (Eds.), Social Pedagogy and Working with Children and Young People: Where Care and Education Meet (pp. 33-52). London: Jessica Kingsley Publishers.

Ewing, R. A., \& Smith, D. L. (2003). Retaining Quality Beginning Teachers in the Profession. English Teaching: Practice and Critique, 2, 15-32.

Fallon, P. R., \& Lukas, R. E. B. (2002). The Impact of Financial Crises on Labor Markets, Household Incomes, and Poverty: A Review of Evidence. World Bank Research $O b$ server, 17, 21-45. https://doi.org/10.1093/wbro/17.1.21

Fantilli, R. D., \& McDougall, D. E. (2009). A Study of Novice Teachers: Challenges and Supports in the First Years. Teaching \& Teacher Education, 25, 814-825.

https://doi.org/10.1016/j.tate.2009.02.021 
Fernandes de Araújo, L., \& Bermúdez, M. D. L. P. (2015). Resilienciaenadultos: Unarevisiónteórica. Terapiapsicológica, 33, 257-276.

Fletcher, D., \& Sarkar, M. (2013). Psychological Resilience. European Psychologist, 18, 12-23. https://doi.org/10.1027/1016-9040/a000124

Flores, M. A. (2006). Being a Novice Teacher in Two Different Settings: Struggles, Continuities and Discontinuities. Teachers College Record, 108, 2021-2052. https://doi.org/10.1111/j.1467-9620.2006.00773.x

Fredrickson, B. L. (2004). The Broaden-and-Build Theory of Positive Emotions. Philosophical Transactions of the Royal Society B, 359, 1367-1377. https://doi.org/10.1098/rstb.2004.1512

Galton, M., \& McBeath, J. (2008). Teachers under Pressure. London: Sage.

Garmezy, N. (1974). The Study of Competence in Children at Risk for Severe Psychopathology. In E. J. Anthony, \& C. Koupernik (Eds.), The Child in His Family: Vol. 3. Children at Psychiatric Risk (pp. 77-97). New York: Wiley.

Gibson, S., \& Dembo, M. (1984). Teacher Efficacy: A Construct Validation. Journal of Educational Psychology, 76, 569-582. https://doi.org/10.1037/0022-0663.76.4.569

Glantz, M. D., \& Sloboda, Z. (1999). Analysis and Reconceptualization of Resilience. In M. D. Glantz, \& J. L. Johnson (Eds.), Resilience and Development: Positive Life Adaptations (pp. 109-126). New York: Kluwer Academic.

Goddard, J. T., \& Foster, R. Y. (2001). The Experiences of Neophyte Teachers: A Critical Constructivist Assessment. Teaching and Teacher Education, 17, 349-353. https://doi.org/10.1016/S0742-051X(00)00062-7

Goldstein, S., \& Brooks, R. B. (2007). Understanding and Managing Children's Classroom Behavior: Creating Sustainable, Resilient Classrooms (Vol. 207). New York: John Wiley $\&$ Sons.

González-Arratia, N. I., Reyes, M., Valdez, J. L., \& González, S. (2011). Resiliencia, autoestima y personalidadresistenteenniños y adolescentes con antecedentes de maltrato. Revista Mexicana de Investigaciónen Psicología Social y de la Salud, 1, 51-62.

Goodson, I., \& Hargreaves, A. (Eds.) (1996) Teachers' Professional Lives. London: Falmer Press.

Gordon, K. A. (1995). The Self-Concept and Motivational Patterns of Resilient African American High School Students. Journal of Black Psychology, 21, 239-255. https://doi.org/10.1177/00957984950213003

Gorman, C. (2005). The Importance of Resilience. Time, 165, A52-A55.

Greenfield, B. (2015). How Can Teacher Resilience Be Protected and Promoted? Educational and Child Psychology, 32, 51-68.

Grissmer, D., \& Kirby, S. (1987). Teacher Attrition: The Uphill Climb to Staff the Nation's Schools. Santa Monica, CA: Rand Corporation.

Gu, Q., \& Day, C. (2007). Teacher's Resilience: A Necessary Condition for Effectiveness. Teaching and Teacher Educations, 23, 1302-1316. https://doi.org/10.1016/j.tate.2006.06.006

Gu, Q., \& Day, C. (2013). Challenges to Teacher Resilience: Conditions Count. British Educational Research Journal, 39, 22-44.

Guttman, C. (2001). A Hard Sell for Teaching. The Courier UNESCO.

Hanushek, E. A., \& Wößmann, L. (2007). The Role of Education Quality for Economic Growth. World Bank Policy Research Working Paper 4122.

https://doi.org/10.1596/1813-9450-4122 
Hargreaves, A. (1994). Development and Desire: A Postmodern Perspective. Annual Meeting of the American Educational Research. http://files.eric.ed.gov/fulltext/ED372057.pdf http://eric.ed.gov/?id=ED372057

Hargreaves, A. (2000). Mixed Emotions: Teachers' Perceptions of Their Interactions with Students. Teaching and Teacher Education, 16, 811-826. https://doi.org/10.1016/S0742-051X(00)00028-7

Hargreaves, A. (2003). Teaching in the Knowledge Society. Buckingham: Open University Press.

Hellenic Statistical Authority (ELSTAT) (2015). Hellas in Numbers (Special Edition)

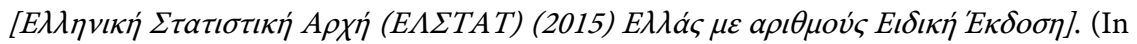
Greek) http://www.statistics.gr/documents/20181/300673/GreeceInFigures_1015_GR.pdf/557c 814b-f984-4caa-ad4f-deac8c1dfa55

Helsby, G. (1999). Multiple Truths and Contested Realities: The Changing Faces of Teacher Professionalism in England. In C. Day, A. Fernandez, T. Hague, \& J. Møller (Eds.), The Life and Work of Teachers (pp. 93-108). London: Falmer.

Henderson, N., \& Milstein, M. M. (1996). Resiliency in Schools: Making It Happen for Students and Educators. Thousand Oaks, CA: Corwin Press.

Higgins, G. O. (1994). Resilient Adults: Overcoming a Cruel past. San Francisco, CA: Jossey-Bass.

Hong, J. Y. (2012). Why Do Some Beginning Teachers Leave the School, and Others Stay? Understanding Teacher Resilience through Psychological Lenses. Teachers and Teaching, 18, 417-440. https://doi.org/10.1080/13540602.2012.696044

Howard, S., \& Johnson, B. (2004). Resilient Teachers: Resisting Stress and Burnout. Social Psychology of Education, 7, 399-420. https://doi.org/10.1007/s11218-004-0975-0

Huberman, M. (1993). The Lives of Teachers. London: Cassell.

Jarzabkowski, L. M. (2002). The Social Dimensions of Teacher Collegiality. Journal of Educational Enquiry, 3, 1-20.

Jenkins, K., Smith, H., \& Maxwell, T. (2009). Challenging Experiences Faced by Beginning Casual Teachers: Here One Day and Gone the Next! Asia-Pacific Journal of Teacher Education, 37, 63-78. https://doi.org/10.1080/13598660802616443

Johnson, B., Down, B., Le Cornu, R., Peters, J., Sullivan, A., Pearce, J. et al. (2014). Promoting Early Career Teacher Resilience: A Framework for Understanding and Acting. Teachers and Teaching: Theory and Practice, 20, 530-546. https://doi.org/10.1080/13540602.2014.937957

Kaldi, S. (2009). Student Teachers' Perceptions of Self-Competence in and Emotions/ Stress about Teaching in Initial Teacher Education. Educational Studies, 35, 349-360. https://doi.org/10.1080/03055690802648259

Kekes, I., \& Mylonakou, I. (2006). Syneducational Transactions among Students, Parents, Educators and Policy Makers: The Transdisciplinary Program SYNTHESIS. Interactive Learning Environments, 14, 35-54. https://doi.org/10.1080/10494820600711496

Kim-Cohen, J. (2007). Resilience and Developmental Psychopathology. Child and Adolescent Psychiatric Clinics of North America, 16, 271-283. https://doi.org/10.1016/j.chc.2006.11.003

Kitching, K., Morgan, M., \& O'Leary, M. (2009). It's the Little Things: Exploring the Importance of Commonplace Events for ECTs' Motivation. Teachers and Teaching: Theory and Practice, 15, 43-58. https://doi.org/10.1080/13540600802661311

Kneale, D., Marjoribanks, D., \& Sherwood, C. (2014). Relationships, Recession and Re- 
covery: The Role of Relationships in Generating Social Recovery. Relate Research Report.

https://www.relate.org.uk/sites/default/files/publication-social-recession-report-sept20 14_0.pdf

Kolar, K. (2011). Resilience: Revisiting the Concept and Its Utility for Social Research. International Journal of Mental Health and Addiction, 9, 421-433. https://doi.org/10.1007/s11469-011-9329-2

Kyriacou, C. (1987). Teacher Stress and Burnout: An International Review. Educational Research, 29, 146-152. https://doi.org/10.1080/0013188870290207

Kyriacou, C. (2000). Stress Busting for Teachers. Cheltenham: Stanley Thornes.

Le Cornu, R. (2009). Building Resilience in Pre-Service Teachers. Teaching and Teacher Education, 25, 717-723. https://doi.org/10.1016/j.tate.2008.11.016

Le Cornu, R. (2013). Building Early Career Teacher Resilience: The Role of Relationships. Australian Journal of Teacher Education, 38, 1-16. https://doi.org/10.14221/ajte.2013v38n4.4

Leithwood, K., Day, C., Sammons, P., Harris, A., \& Hopkins, D. (2006). Successful School Leadership: What It Is and How It Influences Pupil Learning. Nottingham: DfES Publications.

Luthans, F., Avolio, B. J., Avey, J. B., \& Norman, S. M. (2007). Positive Psychological Capital: Measurement and Relationship with Performance and Satisfaction. Personnel Psychology, 60, 541-572. https://doi.org/10.1111/j.1744-6570.2007.00083.x

Luthar, S., S. (1996) Resilience: A Construct of Value? Paper Presented at the 104th Annual Convention of the American Psychological Association, Toronto.

Luthar, S. S. (2006). Resilience in Development: A Synthesis of Research across Five Decades. In: D. Cicchetti, \& D. J. Cohen (Eds.), Developmental Psychopathology: Risk, Disorder, and Adaptation (pp. 739-795). New York: Wiley.

Luthar, S. S., \& Brown, P. (2007). Maximizing Resilience through Diverse Levels of Inquiry: Prevailing Paradigms, Possibilities, and Priorities for the Future. Development and Psychopathology, 19, 931-955. https://doi.org/10.1017/S0954579407000454

Luthar, S. S., \& Cicchetti, D. (2000). The Construct of Resilience: Implications for Interventions and Social Policies. Development and Psychopathology, 12, 857-885. https://doi.org/10.1017/S0954579400004156

Luthar, S. S., Cicchetti, D., \& Becker, B. (2000). The Construct of Resilience: A Critical Evaluation and Guidelines for Future Work. Child Development, 71, 543-562. https://doi.org/10.1111/1467-8624.00164

Masten A. S. (1994). Resilience in Individual Development: Successful Adaptation Despite Risk and Adversity. In M. C. Wang, \& E. W. Gordon, (Eds.), Educational Resilience in Inner-City America: Challenges and Prospects (pp. 3-25). Hillsdale, NY: Lawrence Erlbaum.

Masten, A. S. (2001). Ordinary Magic: Resilience Process in Development. American Psychologist, 56, 227-239. https://doi.org/10.1037/0003-066X.56.3.227

Masten, A. S., Best, K. M., \& Garmezy, N. (1990). Resilience and Development: Contributions from the Study of Children Who Overcome Adversity. Development and Psychopathology, 2, 425-444. https://doi.org/10.1017/S0954579400005812

Matheson, I. (2007). Current Demographics in the School Teacher Population in Scotland. Paper Presented at the Scottish Educational Research Association Conference, Scotland.

http://www.gtcs.org.uk/web/files/formuploads/current-demographics-in-the-school-te aching-population-in-scotland1763_324.pdf 
McCann, C. M., Beddoe, E., McCormick, K., Huggard, P., Kedge, S., Adamson, C., \& Huggard, J. (2013). Resilience in the Health Professions: A Review of Recent Literature. International Journal of Wellbeing, 3, 60-81. https://doi.org/10.5502/ijw.v3i1.4

McCormack, A., \& Gore, J. (2008). "If Only I Could Just Teach”: Early Career Teachers, Their Colleagues, and the Operation of Power. Paper Presented at the Australian Association for Research in Education, Brisbane. http://www.aare.edu.au/data/publications/2008/mcc08185.pdf

Meister, D. G., \& Ahrens, P. (2011). Resisting Plateauing: Four Veteran Teachers' Stories. Teaching and Teacher Education, 27, 770-778. https://doi.org/10.1016/j.tate.2011.01.002

Milstein, M. M., \& Henry, D. A. (2000). Spreading Resiliency: Making It Happen/or Schools and Communities. Thousand Oaks, CA: Corwin Press.

Ministerial Council on Employment, Education, Training and Youth Affairs (MCEETYA) (2004). Demand and Supply of Primary and Secondary School Teachers in Australia. Melbourne: CESCEO National Teacher Supply and Demand Working Party.

Morgan, M., Ludlow, L., Kitching, K., O'Leary, M., \& Clarke, A. (2010). What Makes Teachers Tick? Sustaining Events in New Teachers' Lives. British Educational Research Journal, 36, 191-208. https://doi.org/10.1080/01411920902780972

Morin, R., \& Kochhar, R. (2010). The Impact of Long-Term Unemployment Lost Income, Lost Friends-and Loss of Self-Respect. PewResearch Center. http://assets.pewresearch.org/wp-content/uploads/sites/3/2010/11/760-recession.pdf

Mylonakou, I., \& Kekes, I. (2005). Syneducation (Synekpaidefsis): Reinforcing Communication and Strengthening Cooperation among Students, Parents and Schools. Harvard Family Research Project, Cambridge, MA: Harvard Graduate School of Education. http://www.hfrp.org/content/download/1262/48765/file/syneducation.pdf

Mylonakou, I., \& Kekes, I. (2007). School, Family and the Community in Cooperation: The Model of Syneducation. International Journal about Parents in Education, 1, 73-82.

Mylonakou-Keke, I. (2015a). Social Pedagogy and School Community. Preventing Bullying in Schools and Dealing with Diversity: Two Sides of the Same Coin. International Journal of Social Pedagogy, 4, 65-84.

Mylonakou-Keke, I. (2015b). The Emergence of "Syn-Epistemic Wholeness" from Dialectic Synergy of Disciplines: A Transdisciplinary Social Pedagogic Model. Creative Education, 6, 1890-1907. https://doi.org/10.4236/ce.2015.617195

Mylonakou-Keke, I. (2015c). 1844-2014: 170 Years of Social Pedagogy. Can Economic Crisis Highlight the Potential of Social Pedagogy? International Journal of Social Pedagogy. Special Issue on "Social Pedagogy in times of crisis in Greece", 2-23.

O’Neill, B., \& Xiao J. J. (2012). Financial Behaviors before and after the Financial Crisis: Evidence from an Online Survey. Journal of Financial Counseling and Planning, 23, 33-46. http://afcpe.org/assets/pdf/v23_j3.pdf

OECD (2005). Teachers Matter: Attracting, Developing and Retaining Effective Teachers. Paris: OECD. https://www.oecd.org/edu/school/34990905.pdf

Oswald, M., Johnson, B., \& Howard, S. (2003). Quantifying and Evaluating Resilience Promoting Factors-Teachers' Beliefs and Perceived Roles. Research in Education, 70, 50-64. https://doi.org/10.7227/RIE.70.5

Papatraianou, L. H., \& LeCornu, R. (2014). Problematizing the Role of Personal and Professional Relationships in Early Career Teacher Resilience. Australian Journal of Teacher Education, 39, 100-116. https://doi.org/10.14221/ajte.2014v39n1.7 
Parker, P., \& Martin, A. J. (2009). Coping and Buoyancy in the Workplace: Understanding Their Effects on Teachers' Work-Related Well-Being and Engagement. Teaching and Teacher Education, 25, 68-75. https://doi.org/10.1016/j.tate.2008.06.009

Patterson, J. H., Collins, L., \& Abbott, G. (2004). A Study of Teacher Resilience in Urban Schools. Journal of Instructional Psychology, 31, 3-11.

Pence, A. R. (1998). Ecological Research with Children and Families: From Concepts to Methodology. New York: Teachers' College Press.

Peng, S. (1994). Understanding Resilient Students. The Use of National Longitudinal Databases. In M. C Wang, \& E. W. Gordon, (Eds.), Educational Resilience in Inner-City America: Challenges and Prospects (pp. 73-84). London: Routledge.

Peterson, C., Park, N., \& Sweeney, P. (2008). Group Well-Being: Morale from a Positive Psychology Perspective. Applied Psychology: An International Review, 57, 19-36. https://doi.org/10.1111/j.1464-0597.2008.00352.x

Petrie, P. (2011). Communication Skills for Working with Children and Young People: Introducing Social Pedagogy. London: Jessica Kingsley Publishers.

Pina Lopez, J. A. (2015). Unanálisiscrítico del concepto de resilienciaenpsicología. Anales de Psicología, 31, 751-758.

PricewaterhouseCoopers (2001). Teacher Workload Study. London: DfES.

Priestley, M., Edwards, R., Priestley, A., \& Miller, K. (2012). Teacher Agency in Curriculum Making: Agents of Change and Spaces for Maneuver. Curriculum Inquiry, 42, 191-214. https://doi.org/10.1111/j.1467-873X.2012.00588.x

Richardson, G. E. (2002). The Metatheory of Resilience and Resiliency. Journal of Clinical Psychology, 58, 307-321. https://doi.org/10.1002/jclp.10020

Richardson, G. E., Neiger, B. L., Jenson, S., \& Kumpfer, K. L. (1990). The Resiliency Model. Health Education, 21, 33-39.

Rirkin, M., \& Hoopman, M. (1991). Moving beyond Risk to Resiliency. Minneapolis, MN: Minneapolis Public School.

Rutter, M. (1985). Resilience in the Face of Adversity-Protective Factors and Resistance to Psychiatric-Disorder. British Journal of Psychiatry, 147, 598-611. https://doi.org/10.1192/bjp.147.6.598

Rutter, M. (1990). Psychosocial Resilience and Protective Mechanisms. In J. Rolf, A. S. Masten, D. Cicchetti, K. H. Nuechterlein, \& S. Weintraub (Eds.), Risk and Protective Factors in the Development of Psychopathology (pp. 181-214). New York: Cambridge University Press. https://doi.org/10.1017/CBO9780511752872.013

Rutter, M. (2006). Implications of Resilience Concepts for Scientific Understanding. Annuals of the New York Academy of Sciences, 1094, 1-12. https://doi.org/10.1196/annals.1376.002

Rutter, M., Maughan, B., Mortimer, P., \& Ousten, J. (1979). Fifteen-Thousand Hours: Secondary Schools and Their Effects on Children. Cambridge, MA: Harvard University Press.

Sachs, S. K. (2004). Evaluation of Teacher Attributes as Factors of Success in Urban Schools. Journal of Teacher Educations, 55, 177-187. https://doi.org/10.1177/0022487103261569

Santos, R. S. (2012). Why Resilience? A Review of Literature of Resilience and Implications for Further Educational Research. Qualifying Paper, Claremont, CA: Claremont Graduate University.

https://go.sdsu.edu/education/doc/files/01370-ResiliencyLiteratureReview\%28SDSU\%2 9.pdf 
Schlichte, J., Yssel, N., \& Merbler, J. (2005). Pathways to Burnout: Case Studies in Teacher Isolation and Alienation. Preventing School Failure, 50, 35-40. https://doi.org/10.3200/PSFL.50.1.35-40

Schufeli, W. B., \& Bakker A. B. (2004). Job Demands, Job Resources, and Their Relationship with Burnout and Engagement: A Multi-Sample Study. Journal of Organizational Behavior, 25, 293-315. https://doi.org/10.1002/job.248

Seligman, M. E. P., \& Csikszentmihalyi, M. (2000). Positive Psychology: An Introduction. American Psychologist, 55, 5-14. https://doi.org/10.1037/0003-066X.55.1.5

Smolka, M. N., Buhler, M., Schumann, G., Klein, S., Hu, X. Z., Moayer, M. et al. (2007). Gene-Gene Effects on Central Processing of Aversive Stimuli. Molecular Psychiatry, 12, 307-317. https://doi.org/10.1038/sj.mp.4001946

Southwick, S. M., Bonanno, G. A., Masten, A. S., Panter-Brick, C., \& Yehuda, R. (2014). Resilience Definitions, Theory, and Challenges: Interdisciplinary Perspectives. European Journal of Psychotraumatology, 5, 1-14. https://doi.org/10.3402/ejpt.v5.25338

Stanford, B. H. (2001). Reflections of Resilient Persevering Urban Teachers. Teacher Education Quarterly, 28, 75-87.

Tait, M. (2008). Resilience as a Contributor to Novice Teacher Success, Commitment, and Retention. Teacher Education Quarterly, 35, 57-76.

Tschannen-Moran, M., \& Hoy, A. (2007). The Differential Antecedents of Self-Efficacy Beliefs of Novice and Experienced Teachers. Teaching and Teacher Education, 23, 944-956. https://doi.org/10.1016/j.tate.2006.05.003

Tsouloupas, C. N., Carson, R. L., Matthews, R., Grawitch, M. J., \& Barber, L. K. (2010). Exploring the Association between Teachers' Perceived Student Misbehaviour and Emotional Exhaustion: The Importance of Teacher Efficacy Beliefs and Emotion Regulation. Educational Psychology, 30, 173-189. https://doi.org/10.1080/01443410903494460

Ungar, M. (2008). Resilience across Cultures. British Journal of Social Work, 38, 218-235. https://doi.org/10.1093/bjsw/bcl343

Ungar, M., \& Liebenberg, L. (2011). Assessing Resilience across Cultures Using Mixed Methods: Construction of the Child and Youth Resilience Measure. Journal of Multiple Methods in Research, 5, 126-149. https://doi.org/10.1177/1558689811400607

Vinaccia, S., Quiceno, J. M., \& Moreno-San Pedro, E. (2007). Resiliencia en adolescentes. Revista Colombiana de Psicología, 16, 139-146.

Wagnild, G. M. (2016). The Resilience Scale User's Guide. Worden, MT: Resilience Center.

Wagnild, G. M., \& Young, H. M. (1993). Development and Psychometric Evaluation of the Resilience Scale. Journal of Nursing Measurement, 1, 165-178.

Walsh, F. (1998). Strengthening Family Resilience. New York: The Guilford Press.

Walsh, F. (2007). Traumatic Loss and Major Disasters: Strengthening Family and Community Resilience. Family Process, 46, 207-227. https://doi.org/10.1111/j.1545-5300.2007.00205.x

Wang, M. C., Haertel, G., \& Walberg, H. J. (1993). Synthesis of Research: What Helps Students Learn? Educational Leadership, 51, 74-79.

Waxman, H. C., Gray, J. P., \& Padrón, Y. N. (Eds.) (2004). Educational Resiliency: Student, Teacher, and School Perspectives. Greenwich, CT: Information Age.

Webb, R., Vulliamy, G., Hämäläinen, S., Sarja, A., Kimonen, E., \& Nevalainen, R. (2004). Pressures, Rewards and Teacher Retention: A Comparative Study of Primary Teaching in England and Finland. Scandinavian Journal of Educational Research, 48, 169-188. https://doi.org/10.1080/0031383042000198530 
Werner, E. E. (1993). Risk, Resilience, and Recovery: Perspectives from the Kauai Longitudinal Study. Development and Psychopathology, 5, 503-515.

https://doi.org/10.1017/S095457940000612X

Werner, E. E. (2006). What Can We Learn about Resilience from Large-Scale Longitudinal Studies? In S. Goldstein, \& R. B. Brooks (Eds.), Handbook of Resilience in Children (pp. 91-106). New York: Springer.

Werner, E. E., \& Smith, R. S. (1992). Overcoming the Odds: High Risk Children from Birth to Adulthood. Ithaca, NY: Cornell University Press.

Williams, J. S. (2003). Why Great Teacher Stay [Commentary]. Educational Leadership, $60,71-75$.

Wolin, S. J., \& Wolin, S. (1993). The Resilient Self: How Survivors of Troubled Families Arise above Adversity. New York: Villard Books.

Woolfolk Hoy, A., \& Burke Spero, R. (2005). Changes in Teacher Efficacy during the Early Years of Teaching: A Comparison of Four Measures. Teaching and Teacher Education, 21, 343-356. https://doi.org/10.1016/j.tate.2005.01.007

Wu, G., Feder, A., Cohen, H., Kim, S. S., Calderom, S., Charney, P. S., \& Mathé A. A. (2013). Understanding Resilience. Frontiers in Behavioral Neuroscience, 7, 1-15. https://doi.org/10.3389/fnbeh.2013.00010

Zucker, R. A. (2006). Alcohol Use and the Alcohol Use Disorders: A Developmental-Biopsychosocial Systems Formulation Covering the Life Course. In: D. Cicchetti, \& D. Cohen (Eds.), Developmental Psychopathology. Vol. 3: Risk, Disorder, and Adaptation (pp. 620-656). New York: Wiley.

\section{Submit or recommend next manuscript to SCIRP and we will provide best} service for you:

Accepting pre-submission inquiries through Email, Facebook, LinkedIn, Twitter, etc. A wide selection of journals (inclusive of 9 subjects, more than 200 journals) Providing 24-hour high-quality service User-friendly online submission system Fair and swift peer-review system Efficient typesetting and proofreading procedure Display of the result of downloads and visits, as well as the number of cited articles Maximum dissemination of your research work

Submit your manuscript at: http://papersubmission.scirp.org/

Or contact psych@scirp.org 